Jurnal Penelitian Pendidikan Geografi Volume 4. Nomor 2 April 2019

\title{
PERILAKU MASYARAKAT DALAM MEMBUANG SAMPAH RUMAH TANGGA DI KELURAHAN WALI KECAMATAN WATOPUTE
}

\author{
Andi Putra', La Ode Amaluddin ${ }^{2}$ \\ andigeo.putra@gmail.com

\begin{abstract}
${ }^{1}$ Alumni Pendidikan Geografi Universitas Halu Oleo
${ }^{2}$ Dosen Pendidikan Geografi Universitas Halu Oleo
\end{abstract}

\begin{abstract}
Abstrak : Tujuan dalam penelitian ini adalah untuk mendapatkan data dan gambaran tentang: 1) Gambaran perilaku masyarakat dalam membuang sampah rumah tangga di Kelurahan Wali Kecamatan Watopute:; 2) Untuk mengetahui upaya yang dapat meningkatkan kesadaran masyarakat dalam pengelolaan sampah rumah tangga di Kelurahan Wali Kecamatan Watopute. Jenis penelitian ini adalah penelitian survei dengan menggunakan metode deskriptif kualitatif. Informan dalam penelitian ini ditentukan berdasarkan teknik random sampling.Berdasarkan analisis data diperoleh kesimpulan bahwa : 1) Sebagian besar responden dalam hal ini masyarakat Kelurahan Wali mempunyai pengetahuan baik tentang membuang sampah yang terdiri dari $41,67 \%$ dan pengetahuan sedang 58,33\%. Sedagkan pengetahuan dalam kategori kurang tidak ada. Sehingga dapat disimpulkan bahwa tingkat pengetahuan responden adalah pada kategori baik. Sikap responde secara umum adalah kategori sikap baik yaitu sebanyak 30 responden (50\%). Sebagian besar responden mempunyai tindakan kurang dalam pengelolaan atau membuang sampah terdiri dari 47\%. Tindakan sedang di Kelurahan Wali 41,67\% dan tindakan dalam kategori baik sebanyak 13,33\%. Dapat disimpulkan bahwa tindakan responden di Kelurahan Wali dalam kategori tindakan kurang. Sehingga dapat dikatakan bahawa pengetahuan dan sikap yang baik tidak diikuti tindakan yang baik juga. Secara umum masyarakat mengelola sampah rumah tangga dengan cara membakar, menimbun dan membuang sampah di kawasan hutan; 2) Upaya yang dapat dilakukan untuk meningkatkan kesadaran masyarakat dalam pengelolaan sampah rumah tangga adalah salah satunya dengan pelaksanaan kegiatan bakti sosial.
\end{abstract}

Kata Kunci: Pengelolaan Sampah, Perilaku Masyarakat 
Jurnal Penelitian Pendidikan Geografi Volume 4. Nomor 2 April 2019

\title{
THE BEHAVIOR OF THE COMMUNITY IN DISPOSING OF HOUSEHOLD TRASHIN THE WATOPUTE SUBDISTRICT WALIVILLAGE
}

\author{
Andi Putra', La Ode Amaluddin ${ }^{2}$ \\ andigeo.putra@gmail.com \\ ${ }^{1}$ Alumni Of Halu Oleo University Geography Education \\ ${ }^{2}$ Lecturer Of Halu Oleo University Geography Education
}

\begin{abstract}
The purpose of this study was to obtain data and descriptions about: 1) A description of the behavior of the community in disposing of household trash in the Wali Village, Watopute Sub-district ; 2) To find out the efforts that can increase public awareness in household waste management in Wali Village, Watopute Su-district. This type of research is survey research using qualitative descriptive methods. The informants in this study were determined based on random sampling technique.Based on the data analysis, it can be concluded that: 1)Based on the results of the research, most of the respondents in this case the community of sub-district wali have good knowledge about disposing of garbage consisting of $41.67 \%$ and moderate knowledge $58.33 \%$. Whereas knowledge in the less category does not exist. The attitude of respondents in general is a good attitude category that is as many as 30 respondents (50\%). The majority of respondents have less action in managing or disposing of waste consisting of 47\%. Moderate actions in the guardian's area $41.67 \%$ and actions in good category as much as $13.33 \%$. To further increase management awareness in this case to dispose of good garbage, it is hoped that there will be a role for the city cleaning service to provide garbage disposal facilities that meet the requirements. Increasing community participation in the implementation of hygiene programs in each neighborhood. 2) A good and correct way of disposing of garbage is disseminated to each region, both the village, the village and in the city by the relevant agencies
\end{abstract}

Keywords : Manage waste, Community Behavior.

\section{PENDAHULUAN}

Kebersihan pangkal kesehatan artinya, lingkungan yang sehat berawal dari lingkungan yang bersih. Salah satu penyebab lingkungan kotor adalah sampah. Keberadaan sampah disebabkan oleh aktivitas kehidupan dan kegiatan manusia. Pesatnya pertumbuhan penduduk, penggunaan lahan semakin meningkat akibat desakan pembangunan akanmempunyai dampak yang mempengaruhi sumber-sumber alam dan kualitas lingkungan. Salah satu contohnya adalah sampah. Masalah sampah di Indonesia adalah masalah yang rumit karena kurangnya pengertian masyarakat terhadap akibat-akibat yang ditimbulkan oleh sampah, kurangnya biaya pemerintah untuk mengusahakan pembuangan sampah yang baik dan memenuhi syarat.

Faktor lain yang menyebabkan permasalahan sampah di Indonesia semakin rumit adalah meningkatnya taraf hidup masyarakat, yang tidak disertai dengan keselarasan pengetahuan tentang persampahan dan juga partisipasi masyarakat yang kurang untuk memelihara 
Jurnal Penelitian Pendidikan Geografi Volume 4. Nomor 2 April 2019

kebersihan dan membuang sampah pada tempatnya (Slamet, 2002).

Sampah adalah sesuatu yang tidak dipakai, tidak disenangi atau sesuatu yang harus dibuang yang umumnya berasal dari kegiatan yang dilakukan oleh manusia tetapi bukan biologis karena kotoran manusiadidalamnya bersifat padat (air bekas tidak termasuk didalamnya) (Azwar, 2008).

Produksi sampah perseorangan maupun rumah tangga setiap harinya tidak dapat dipisahkan dari setiap kegiatan kehidupan manusia itu sendiri. Khususnya sampah rumah tangga, berkaitan juga dengan tingkat pendapatan, tingkat pendidikan dan besarnya keluarga.

Bersamaan dengan kenaikan jumlah penduduk serta kebutuhan yang kompleks menuntut masyarakat untuk memenuhinya. Akibatnya pola hidup masyarakat lebih cenderung meningkat dan konsumtif. Limbah yang dihasilkan perorang makin besar padahal jumlah penduduk semakin bertambah. Logikanya adalah semakin banyak jumlah penduduk semakin banyak pula sampah yang dihasilkan. Semantara pendapatan kita untuk menangani sampah masih terbatas. Akibatnya, didaerah perdesaan banyak sampah yang tertumpuk atau berserakan.

Pengolahan sampah diperdesaan umumnya dilakukan dengan cara membakar, menanam dalam lubang, dan tidak jarang dibuang kedalam selokan dan ditumpuk dipekarangan belakang rumah dan kebun. Berbagai carapun telah dijalani termasuk para ahli untuk menanggulangi sampah, termasuk cara mendaur ulang, namun cara-cara tersebut masih belum memecahkan masalah sampah yang semakin meningkat jumlah dan jenisnya, baik diperdesaan maupun daerah kumuh diperkotaan (Dainur, 1993).

Dari survei awal yang dilakukan oleh peneliti di Kelurahan Wali Kecamatan Watopute sebagian besar masyarakat mengelolah sampah dengan membakar, membuang ke lahan kosong bahkan dalam kawasan hutan. Apabila dibiarkan terus menerus maka akan membawa dampak yang lebih besar kedepannya. Oleh karena itu, diperlukan sebuah upaya mengkaji tentang kondisi atau prilaku masyarakat dalam pengelolaan sampah. Itulah alasan peneliti mengangkat sebuah penelitian yang berjudul "Perilaku Masyarakat Dalam Membuang Sampah Rumah Tangga Di Kelurahan Wali Kecamatan Watopute".

Perilaku merupakan semua kegiatan atau aktivitas diamati langsung maupun tidak diamati oleh pihak luar. Meurut Skinner (1938) yang dikutip Notoatmojo (2003) menegakan perilaku itu merupakan respon atau reaksi orang terhadap rangsangan atau stimulus dari luar.

Bloom (1908), seorang psikologi pendidikan membagi perilaku manusia itu kedalam 3 kawasan yakni Kognitif, Afektif, dan Psikomotor. Komponen kognitif terdiri dari seluruh kognisi yang dimiliki seorang yang mengenai objek tertentu seperti pengetahuan dan keyakinan tentang objek. Komponen afektif terdiri dari penilaian dan komponen psikomotor terdiri dari kesiapan seseorang untuk bereaksi atau kecenderungan untuk bertindak terhadap objek (Notoatmojo, 2003).

Dalam perkembangannya, teori bloom ini dimodifikasi untuk pengukuran hasil pendidikan kesehatan yakni:

\section{a. Pengetahuam (Knowledge)}

Pengetahuan merupakan hasil dari tahu, dan ini terjadi setelah orang melakukan pengindraan. Pengetahuan atau kognitif merupakan domain yang sangat penting dalam membentuk tindakan seseorang.

\section{b. Sikap}

Sikap merupakan reaksi atau respon yang masih tertutup dari seseorang terhadapsuatu stimulus atau objek. Sikap secara nyata menunjukan konotasi adanya kesesuaian reaksi terhadap stimulus tertentu yang dalam kehidupan sehari-hari merupakan reaksi yang bersifat emosional 
Jurnal Penelitian Pendidikan Geografi Volume 4. Nomor 2 April 2019

terhadap stimulus sosial. Sikap merupakan kesedianan untuk bertindak, dan bukan pelaksanaan motif tertentu. Sikap belum merupakan suatu tindakan atau aktivitas, akan tetapi merupakan predisposisi tindakan suatu perilaku.

Allport (1954) menjelaskan bahwa sikap itu mempunyai 3 komponen pokok yaitu : (1) Kepercayaan (Keyakinan), ide dan konsep terhadap suatu objek. (2) kehidupan emosional atau evaluasi terhadap suatu objek. (3) kecenderungan untuk bertindak.

\section{c. Praktek Atau Tindakan}

Suatu sikap belum otomatis terwujud dalam suatu tindakan. Untuk mewujudkan sikap menjadi suatu perbutan nyata diperlukan faktor pendukung atau suatu kondisi yang memungkinkan, antara lain fasilitas. Disamping itu juga diperlukan faktor dukungan dari pihak luar.

Sampah adalah sisa-sisa bahan yang mengalami perlakuan-perlakuan, baik karena telah diambil bagian utamanya, atau karena pengolahan,atau karena sudah tidak ada manfaatnya, yang ditinjau dari segi ekonomis tidak ada harganya dan dari segi lingkungan dapat menyebabkan pencemaran dan gangguan kelestarian.

Saat ini tidak bisa dipungkiri jikamasih banyak masyarakat yang berperilakuburuk tentang sampah Mereka membuangsampah sembarangan. Perilaku ini tidakmengenal tingkat pendidikan maupun statussosial. Keberadaan sampah di kehidupansehari-hari tak lepas dari tangan manusiayang membuang sampah sembarangan,mereka menganggap barang yang telahdipakai tidak memiliki kegunaan lagi danmembuang dengan seenaknya sendiri.Kurang kesadaran akan pentingnyakebersihan menjadi faktor yang palingdominan, di samping itu kepekaanmasyarakat terhadap lingkungan harusdipertanyakan. Mereka tidak mengetahuibahaya apa yang akan terjadi apabila tidakdapat menjaga lingkungan sekitar (Nurdin,2004).
Pengelolaan sampah adalah suatu bidang yang berhubungan dengan pengendalian terhadap penimbunan, penyimpanan sementara, pengumpulan, pemindahan, dan pengangkutan, pemprosesan dan pembuangan dengan suatu cara yang, sesuai dengan prinsip terbaik dari kesehatan masyarakat, ekonomi, teknik, konvensasi, estetika pertimbanganpertimbangan lingkungan yang lain dan juga sikap masyarakat (Juli Soemirat Slamet, 2002:154).

Sedangkan Hadiwiyoto (1983) mendefenisikan pengelolaan dengan penangan, dimana yang dimaksud "penanganan"ialah perlakuan terhadap sampah untuk memperkecil atau menghilangkan masalah-maslah yang muncul berkaitan dengan lingkungan. Penanganan sampah dapat berbentuk semata-mata membuang sampah, atau mengembalikan (recycling) sampah menjadi bahan-bahan yang bermanfaat. Tahap pertama dalam penanganan sampah ialah mengumpulkan sampah dari berbagai tempat ke suatu lokasi pengumpulan, sesudah itu diadakan pemisahan komponen sampah menurut sifatnya.

Pengelolaan sampah meliputi tiga kegiatan yaitu:

- Pengumpulan atau penyimpanan;

- Pengangkutan; dan

- Pemusnahan/pembuangan.

\section{METODE PENELITIAN}

\section{Waktu dan Tempat Penelitian}

Penelitian ini dilaksanakan pada bulan Juni - Juli 2018. Lokasi atau tempat menelitian adalah di Kelurahan Wali Kecamatan Watopute Kabupaten Muna. Lokasi ini dipilih dengan pertimbangan bahwa terdapatnya banyak sampah yang berserakkan disekitar rumah masyarakat akibat dari pembuangan sampah secara sembarangan di Kelurahan Wali Kecamatan Watopute.

\section{Jenis Penelitian}

Andi Putra, La Ode Amaluddin 
Jenis penelitian ini adalah penelitian Survei yaitu suatu metode penelitian yang dilakukan dengan tujuan utama untuk membuat gambaran atau deskripsi tentang suatu keadaan secara obyektif.

\section{Responden dan Informan}

Responden dalam penelitian ini adalah masyarakat di Kelurahan Wali Kecamatan Watopute yang berjumlah 60 orang yang diambil dengan cara menggunakan Random Samplig.

\section{Instrumen Penelitian dan Aspek Pengukuran}

\section{Instrumen Penelitian}

Instrumen yang dipakai untuk pengumpulan data adalah kuisioner yang berisi pertanyaan tentang pengetahuan, sikap dan tindakan masyarakat dalam pengelolaan sampah. Pada masing-masing aspek dibagi menjadi empat komponen yaitu mengenai pengumpulan sampah, pemisaha sampah, pembakaran sampah, dan penimbunan sampah. Pemilahan setiap komponen bertujuan agar lebih terstruktur dan mudah dipahami oleh responden.

\section{Aspek Pengukuran}

Data yang diperoleh dianalisis dalam pengukuran aspek prilaku. Ada 3 (tiga) jenis variabel yang dianalisis yaitu pengetahuan, sikap dan tindakan. Menurut Pratomo (1986) dikutip Lasma Rohani (2007) memberikan gambaran untuk mengklasifikasikan dengan perhitungan sebagai berikut:

- Tingkat pengetahuan, sikap dan tindakan baik jika total skor $>75 \%$

- Tingkat pengetahuan, sikap dan tindakan sedang jika total skor $40 \%$ $75 \%$

- Tingkat pengetahuan, sikap dan tindakan kurang jika total skor $<40 \%$.

\section{Teknik Pengumpulan Data}

Teknik pengumpulan data dalam penelitian ini dibatasi pada data primer dan data sekunder. Data primer merupakan data yang didapat dari sumber pertama, sedangkan data sekunder merupakan data primer yang telah diolah lebih lanjut. Data primer diperoleh dengan cara wawancara dengan menggunakan kuisioner kepada responden.

\section{Teknik Analisis Data}

Analisa data dilakukan dengan menggunakan analisis yang bersifat deskriptif untuk mengetahui gambaran perilaku masyarakat dalam pengelolaan sampah. Pengolahan data dilakukan secara manual (presentase) dan disajikan dalam bentuk tabel distribusi frekuensi untuk mengetahui tingkat pengetahuan, sikap dan tindakan masyarakat dalam pengelolaan sampah di Kelurahan Wali Kecamatan Watopute.

Anaisis data hasil penelitian dilakukan dengan beerapa cara untuk memperoleh hasil yang diinginkan dan seuai dengan kedaan yang sebenaarnya yaitu:

1) Menurunkan data dalam bentuk tabel presentase tentang priaku dalam membuang sampah baik dalam betuk pengetahuan, sikap, maupun tindakan masyarakat di kelurahan wali sehingga diperoleh data kesimpulan dari respoden dengan menggunakan rumus sebagi berikut:

$$
\mathrm{P}=\frac{\mathrm{F}}{N} \times 100 \%
$$

Keterangan:

$\mathrm{P}=$ Kategori ( Presentase pilihan )

$\mathrm{F}=$ Frekwensi ( Jumlah respoden yang memilih alternatif sama )

$\mathrm{N}=$ Jumlah responden keseluruhan $100=$ Presentase $(\%)$

2) Menarik kesimpulan tertetu dari hasil pemahaman dan pegertian peneliti (Faisal, 201:256).

\section{GAMBARAN UMUM LOKASI PENELITIAN}

Kelurahan Wali terletak di Kecamatan Watopute Kabupaten Muna yang terdiri dari yang terdiri dari 4 rukun 
Jurnal Penelitian Pendidikan Geografi Volume 4. Nomor 2 April 2019

Warga. Luas Kelurahan Wali adalah 6,82 $\mathrm{km}$ dengan batas wilayah sebagai berikut :

- Sebelah Utara : Desa Wawesa

- Sebelah Barat : Desa Bangkali

- Sebelah Selatan : Desa Labaha

- Sebelah Timur :Kelurahan

ManggKuning

Jumlah penduduk Kelurahan Wali

secara keseluruhan pada tahu 2016 mencapai 2.433 jiwa yang terdiri dari 1191 jiwa laki-laki dan 1242 jiwa perempuan, dengan jumlah Kepala Keluarga 581 yang tersebar di masing-masing RW. Persebaran penduduk sebesar $19,03 \%$.

\section{HASIL PENELITIAN}

Hasil penelitian ini diperoleh dengan teknik wawancara tertulis mengguakan kuisioner kepada informan sebagai bentuk pecarian data dan dokumentasi langsung dilapagan yang kemudian peneliti analisis. Analisis ini sendiri terfokus pada masyarakat Kelurahan Wali berkaitan dengan perilaku dalam membuang sampah rumah tangga yang diklasifikasi dalam tiga aspek yaitu pengetahuan, sikap dan tindakan masyarakat.

\section{Aspek Pengetahuan Masyarakat Tentang Pengelolaan Sampah Rumah Tangga}

Pengetahuan responden tentang membuang sampah adalah sejauh mana responden tahu akan manfaat mengelolasampah dan dampak yang ditimbulkan oleh sampah terhadap diri serta lingkungan.

Dari hasil penelitian diketahui tingkat pengetahuan responden tentang membuang sampah dengan kategori seperti pada tabel dibawah ini:

$\begin{array}{lllll}\text { Tabel } & \text { 4.1 } & \text { Distribusi } & \text { TingkatPengetahuan }\end{array}$ TentangMembuangSampah DiKelurahan Wali

\begin{tabular}{cccc}
\hline No. & $\begin{array}{c}\text { Kategori } \\
\text { Tindakan }\end{array}$ & $\begin{array}{c}\text { Kelurahan } \\
\text { Wali }\end{array}$ & Persentase (\%) \\
\hline 1 & Baik & 25 & 41,67 \\
\hline 2 & Sedang & 35 & 58,33 \\
\hline 3 & Kurang & - & - \\
\hline & Jumlah & 60 & 100 \\
\hline
\end{tabular}

Sumber: Data diolah (2018

Dari tabel 4.1 dapat diketahui tingkat pengetahuan responden tentang membuang sampah pada kategori baik di Kelurahan wali sebanyak 25 respoden $(41,67 \%)$ dan pada kategori sedang sebanyak 35 responden $(58,33 \%)$ dan kategori pengetahuan kurang tidak ada. Secara umum dapat diketahui bahwa pengetahuan responden dianggap baik karena tidak adanya responden yang masuk dalam kategori pengetahuan kurang.

Tingkatan pengetahuan responden tentang pengelolaan sampah adalah pada tingkatan tahu (Know). Kata kerja untuk mengukur bahwa orang tahu tentang sesuatu adalah menyebutkan, menguraikan,mendefenisikan dan menyatakan. (Notoatmodjo, 2003).

Dari hasil penelitian ini dapat dilihat bahwa kategori pengetahuan responden di Kelurahan Wali adalah dalam kategori baik. Hal ini bisa rerjadi karena karakteristik responden seperti umur yang masi produktif, pendidikan yang cukup tinggi serta pekerjaan responden. 
Jurnal Penelitian Pendidikan Geografi Volume 4. Nomor 2 April 2019

\section{Aspek Sikap Masyarakat Tentang Pengelolaan Sampah Rumah Tangga}

Tabel 4.2 Dari Hasil Penelitian Diketahui Bahwa Tingkat SikapResponden TentangMembuang Sampah Dengan KategoriSeperti Tabel Di BawahIni

\begin{tabular}{cccc} 
No. & $\begin{array}{c}\text { Kategori } \\
\text { Sikap }\end{array}$ & $\begin{array}{c}\text { Kelurahan } \\
\text { Wali }\end{array}$ & $\begin{array}{c}\text { Persentase } \\
(\mathbf{\%})\end{array}$ \\
\hline $\mathbf{1}$ & Baik & 30 & 50 \\
\hline $\mathbf{2}$ & Sedang & 26 & 43,33 \\
\hline $\mathbf{3}$ & Kurang & 4 & 6,67 \\
\hline \multicolumn{2}{c}{ Jumlah } & $\mathbf{6 0}$ & $\mathbf{1 0 0}$ \\
\hline
\end{tabular}

Sumber: Data diolah (2018)

Dari tabel 4.2 dapat diketahui bahwa sikap responden tentang membuang sampah secara umum pada kategori sikap baik yaitu 30 responden $(50 \%)$, sedang 26 responden $(43,33 \%)$, dan kurang 4 responden $(6,67 \%)$. Berdasarkan data tersebut dapat dikatakan bahwa mayoritas responden memiliki sikap baik tentang membuang sampah dan pengelolaannya.

Kalau dikaitkan dengan pengetahuan, umumnya pengerahuan responden dalam kategori baik begitu juga sikap responden menunjukan kategori yang baik. Hal ini sesuai dengan menurut Notoadmodjo (2003) bahwa dalam penentuan sikap pengetahua, berpikir, keyakinan dan emosi memegang peran penting sehingga dapat dikatakan dalam penelitian ini pengetahuan responden berpengaruh dalam menentukan sikap responden pada tingkat menerima dan merespon. Menerima diartikan bahwa responden mau memperlihatkan stimulus yang diberikan dan merespon artinya memberi jawaban apabila ditanya (Notoatmodjo, 2003).

\section{Aspek Tindakan Masyarakat Tentang Pengelolaan Sampah Rumah Tangga}

Tabel 4.3 tabulasi silang tindakan respoden tentang membuangsampah degan kategori seperti tabel dibawah ini

\begin{tabular}{cccc}
\hline No. & Kategori Tindakan & Kelurahan Wali & $\begin{array}{c}\text { Persentase } \\
(\boldsymbol{\%})\end{array}$ \\
\hline $\mathbf{1}$ & Baik & 8 & 13,33 \\
\hline $\mathbf{2}$ & Sedang & 25 & 41,67 \\
\hline $\mathbf{3}$ & Kurang & 27 & 47 \\
\hline & Jumlah & 60 & 100 \\
\hline
\end{tabular}

Sumber: Data diolah (2018)

Dari tabel 4.3 dapat diketahui tidakan responden dalam pengelolaan sampah pada kategori baik di Kelurahan Wali adalah 8 responden $(13,33 \%)$, kategori sedang sebanyak 25 responden $(41,67 \%)$, dan kategori kurang sebanyak 27 responden (47\%). Dari data tersebut bisa dikatakan bahwa mayoritas masyarakat Kelurahan Wali masuk dalam kategori tindakan kurang baik dalam hal membuang sampah dan pengelolaan sampah.

Dari hasil penelitian ini dapat diketahui bahwa pengetahuan dan sikap responden di Kelurahan Wali mayoritas dalam kategori baik dan sedang, sedangkan tindakan mayoritas responden masuk dalam kategori kurang dan sedang. Hal ini ini menunjukkan pengetahuan dan sikap yang baik tidak diikuti tindakan yang baik juga. 
Jurnal Penelitian Pendidikan Geografi Volume 4. Nomor 2 April 2019

Ini terjadi karena perilaku yang baik tidak hanya ditentukan oleh pengetahuan yang baik saja tetapi ada faktor lain juga yang berpengaruh terhadap perilaku seseorang seperti kebiasaan/tradisi, sikap dan perilaku tokoh masyarakat. Hal ini sejalan degan teori yang di kemukakan oleh gree (1980) yang menyatakan bahwa ada 3 (tiga) faktor yang mempengaruhi perilaku yaitu Faktor Predisposisi seperti kebiasaan, tradisi, sikap, pengetahuan, Faktor yang memudahkan (Enebling Factor) seperti ketersediaan fasilitas. Faktor yang memerkuat (Reinfocing Factor) seperti sikap dan periaku petugas kesehatan (Notoatmodjo, 2003).

\section{Upaya Meningkatkan Kesadaran Masyarakat Dalam Pengelolaan Sampah Rumah Tangga.}

Untuk menanamkan perilaku yang baik dan kesadaran dalam pengelolaan sampah pada masyarakat yaitu dengan membiasakan hidup bersih. Perilaku hidup bersih merupakan kebiasaan yang ditunjukan dengan menerapkan hidup sehat atau menjaga lingkungan agar tetap menjadi tempat yang nyaman untuk ditinggali. Perilaku hidup bersih antara lain adalah salah satunya tindakan untuk tidak membuang sampah sembarangan. Dengan demikian hal tersebut, maka perilaku hidup bersih sangat penting untuk selalu terwujudkan dengan baik pada kebiasaankebiasaan warga masyarakat. Oleh karena itu, upaya untuk meningkatkan kesadaran perilaku hidup bersih sangat diperlukan agar selalu dilakukan pembinaan. Upaya yang dapat dilakukan adalah salah satunya dengan pelaksanaan kegiatan bakti sosial. Kegiatan-kegiatan kemasyarakatan yang mengupayakan untuk terbentuknya kerja sama diantara warga masyarakat agar secara bersama-sama menjaga lingkungan.

Kegiatan bakti sosial ini dilaksanakan secara berkala atau menurut dari hasil kesepakatan diantara warga masyarakat. Kegiatan bakti sosial ini diharapkan dapat meningkatkan perilaku hidup bersih. Mengapa demikian, karena dapat memberikan kesadaran untuk terbiasa melakukan perbuatan-perbuatan yang menjaga kebersihan lingkugan. Perlaku hidup bersih dapat ditingkatkan dengan semakin baiknya penyelenggaraan kegiatan bakti sosial. Maka dengan demikian diharapkan dengan melaksanakan kegiatan bakti sosial kemudian dapat menjadi salah satu upaya untuk meningkatkan perilaku hidup bersih.

Berdasarkan uraian diatas maka penelitian ini hendak difokuskan pada pembahasan mengenai bagaimana upaya meningkatkan perilaku masyarakat dalam membuang sampah melalui kegiatan kerja bakti di Kelurahan Wali Kecamatan Watopute.

Upaya untuk meingkatkan perilaku dalam membuang sampah memalui bakti sosial antara lain adalah dapat dilakukan dengan:

a. Menyelenggarakan usaha penyuluhanpenyuluhan kepada warga masyarakat yang dilakukan bekerja sama dengan instansi pemerintah daerah dibidang kebersihan lingkungan sehingga dapat menambah pemahaman dan kesadaran yang lebih baik bagi masyarakat untuk berperilaku bersih.

b. Melakukan kegiatan-kegiatan kerja bakti bersama yang dilakukan secara rutin minimum satu bulan sekali pada masing-masing wilayah lingkungan rukun warga (RW) dengan berkoordinasi antar pengurus rukun tetangga dalam memobilisasi partisipasi warga.

c. Memberikan penghargaan dan apresiasi kepada warga Kelurahan Wali pada lingkungan Rukun Warga (RW) yang dilakukan berupa lomba kebersihan lingkunga kelurahan warga setiap peringatan hari-hari besar nasional.

d. Mengupayakan terbentuknya semacam satuan tugas kebersihan di lingkungan wilayah rukun warga yang mengawasi 
dan mengarahkan perilaku hidup bersih warga masyarakat dengan memberikan sanksi-sanksi tertentu sesuai aturan dan ketentuan yang disepakati dalam musyawarah.

\section{KESIMPULAN}

Dari hasil penelitian tentang perilaku masyarakat dalam membuang sampah rumah tangga di Keluraha Wali dapat disimpulkan sebagai berikut:

1. Sebagian besar responden dalam hal ini masyarakat Kelurahan Wali mempunyai pengetahuan baik tentang membuang sampah yang terdiri dari $41,67 \%$ dan pengetahuan sedang 58,33\%. Sedagkan pengetahuan dalam kategori kurang tidak ada. Sehingga dapat disimpulkan bahwa tingkat pengetahuan responden adalah pada kategori baik. Sikap responde secara umum adalah kategori sikap baik yaitu sebanyak 30 responden (50\%). Sebagian besar responden mempunyai tindakan kurang dalampengelolaan atau membuang sampah terdiri dari 47\%. Tindakan sedang di Kelurahan Wali 41,67\% dan tindakan dalam kategori baik sebanyak 13,33\%. Dapat disimpulkan bahwa tindakan responden di Kelurahan Wali dalam kategori tindakan kurang. Sehingga dapat dikatakan bahawa pengetahuan dan sikap yang baik tidak diikuti tindakan yang baik juga. Secara umum masyarakat mengelola sampah rumah tangga dengan cara membakar, menimbun dan membuang sampah di kawasan hutan.

2. Upaya yang dapat dilakukan untuk meningkatkan kesadaran masyarakat dalam pengelolaan sampah rumah tangga adalah salah satunya dengan pelaksanaan kegiatan bakti sosial.

\section{SARAN}

1. Untuk lebih meningkatkan perilaku pengelolaan dalam hal ini membuang sampah yang baik maka diharapkan adanya peran serta dinas kebersihan kota untuk menyediakan sarana pembuangan sampah yang memenuhi syarat.

2. Meningkatkan peran serta masyarakat dalam pelaksanaan program kebersihan ditiap lingkungan kelurahan.

3. Cara pembuangan sampah yang baik dan benar di sosialisasikan kepada masing-masing daerah, baik kelurahan, desa maupun di kota oleh instansi terkait.

\section{DAFTAR PUSTAKA}

Bloom, B, Psikologi Pendidikan. 1908. Jakarta.

Dianur, 1993, Materi-materi Pokok Ilmu Masyarakat, Jakarta; Widya Medika.

Faisal S. 1990. Penelitian Kuatatis Dasar dan Aplikasi. Malang :YA3.

Hadiwiyoto, Soewedo, Ir, 1983. Penanganan dan Pemanfaatan Sampah. Jakarta: Yayasan dayu

Juli, Soemirat Slamet, 2002. Prinsip Dasar Kesehatan Lingkungan. Yogyakarta: Pustaka Pelajar Offset.

Marojahan, Ricky, 2015, Hubungan Pengetahuan Masyarakat Tentang Sampah Dengan Perilaku Mengelola Sampah Rumah Tangga Di Rt 02 Dan Rt 03 Kampung Garapan Desa Tanjung Pasir Kecamatan Teluk Naga Kabupaten Tangerang, Forum Ilmiah Volume 12 Nomor 1.

Rahman, Adi, 2013. Perilaku Masyarakat Dalam Pengelolaan Sampah Rumah Tangga (Studi Kasus Di Kelurahan Pasar Sarolangun), Jurnal Bina Praja, Volume 5 Nomor 4 Edisi Desember 2013: 215 - 220.

Andi Putra, La Ode Amaluddin 
Jurnal Penelitian Pendidikan Geografi Volume 4. Nomor 2 April 2019

Rohani, Lasma. 2007. Perilaku Masyarakat Dalam Pengelolaan Sampah Di Desa Medan Senembah Kabupaten Deli serdang dan Kelurahan Asam Kumbang Kota Medan. Universitas SumateraUtara: Medan.

Safiuddin, Azwar, 2008. Sikap Manusia Teori dan Pengukurannya, Yogyakarta: Pustaka Pelajar Offset.

Soedikjo, Notoatmodjo, 2003, Pendidikan dan Perilaku Kesehatan, Jakarta: PT Rineka Cipta. 